\title{
Novel and Promising Preparation of an Efficient Hematite Photoanode for Oxygen Evolution Reaction
}

\author{
Takahiro Murakami and Toshiyuki Abe* \\ Department of Frontier Materials Chemistry, Graduate School of Science and Technology, Hirosaki \\ University, 3 Bunkyo-cho, Hirosaki 036-8561, Japan \\ *E-mail: tabe@hirosaki-u.ac.jp
}

doi: $10.20964 / 2020.08 .25$

Received: 6 March 2020 / Accepted: 30 April 2020 / Published: 10 July 2020

Iron(III) oxide $\left(\mathrm{Fe}_{2} \mathrm{O}_{3}\right)$ has been recognized as a photoanode capable of water oxidation to dioxygen. For producing the efficient performance of $\mathrm{Fe}_{2} \mathrm{O}_{3}$ photoanode, the short-range diffusion of hole carriers and the ease of carrier recombination are the issues to be solved. Herein, a promising fabrication method for the preparation of an efficient $\alpha-\mathrm{Fe}_{2} \mathrm{O}_{3}$ photoanode is presented. When $\alpha-\mathrm{Fe}_{2} \mathrm{O}_{3}$ was subjected to acid treatment followed by loading of a co-catalyst, mix-valence cobalt(II,III) oxide $\left(\mathrm{Co}_{3} \mathrm{O}_{4}\right)$, the double-treated $\mathrm{Fe}_{2} \mathrm{O}_{3}$ was superior to the untreated and acid-treated materials.

Keywords: Hematite; acid treatment; $\mathrm{Co}_{3} \mathrm{O}_{4}$; water oxidation; $\mathrm{O}_{2}$ evolution

\section{$\underline{\text { FULL TEXT }}$}

(C) 2020 The Authors. Published by ESG (www.electrochemsci.org). This article is an open access article distributed under the terms and conditions of the Creative Commons Attribution license (http://creativecommons.org/licenses/by/4.0/). 